\title{
PERAMALAN VOLATILITAS DAN ESTIMASI VALUE AT RISK (VAR) SAHAM BLUE CHIP PADA SEKTOR PERBANKAN
}

\author{
Ni Kadek Juliarini ${ }^{1 \S}$, I Wayan Sumarjaya ${ }^{2}$, Kartika Sari ${ }^{3}$ \\ ${ }^{1}$ ProgramStudi Matematika, Faku ltas MIPA-Universitas Uday ana [Email:juliarini90799@yahoo.com] \\ ${ }^{2}$ ProgramStudi Matematika, Fakultas MIPA-Universitas Uday ana [Email:s umarjaya@unud .ac.id] \\ ${ }^{3}$ ProgramStudi Matematika, Fakultas MIPA-Universitas Uday ana [Email:sarikartika@unud.ac.id] \\ ${ }^{\S}$ Corresponding Author
}

\begin{abstract}
Investment is an activity to invest an asset to obtain a greater profit. The investment there's in great demand by investors are stock investments. Based on market capitalization, stocks are classified into first-tier, second-tier, and third-tier stocks. Stocks that have the highest market capitalization are first-tier or blue-chip stocks. Blue-chip stocks are stocks that are classified as main shares on the listing board on the IDX. Before investing, it's important to know the level of investment risk in order to make the right investment decisions. The purpose of this study is to determine the risk of investing in blue-chip stocks namely BRI, BCA, and Bank Mandiri through volatility forecasting using the GARCH, EGARCH, or TGARCH models. The data used is the daily closing price of shares for the period of 25 May 2005 to 21 May 2021 which was obtained through the Yahoo Finance website. Based on the research results, it's known that Bank Mandiri has the highest investment risk and BCA has the lowest investment risk. Based on these results, it can be suggested that investors who like risk can choose to invest in Bank Mandiri shares, and those who don't like risk can invest in BCA shares.
\end{abstract}

Keywords: GARCH, EGARCH, TGARCH, Volatility, VaR

\section{PENDAHULUAN}

Investasi merupakan suatu kegiatan penanaman modal pada sebuah perusahaan atau proyek berupa aset atau dana untuk jangka waktu tertentu dengan tujuan memperoleh imbal hasil yang lebih besar (Tyas et al., 2019). Bursa Efek Indonesia (2020) menyatakan bahwa salah satu jenis investasi yang banyak diminati investor yaitu investasi pada bursa saham karena dapat memberikan tingkat keuntungan yang menarik. Namun jika keuntungan yang diharapkan semakin tinggi, maka risiko yang mungkin ditanggung juga akan semakin tinggi. Oleh karena itu, penting bagi seorang investor untuk mengetahui tingkat risiko investasi agar dapat mengambil keputusan investasi yang tepat. Tsay (2013) menyatakan bahwa ukuran risiko yang umum digunakan yaitu value at risk (VaR). VaR merupakan estimasi kerugian maksimum dalam bentuk persen atau sejumlah uang selama periode waktu dan selang kepercayaan tertentu (Dwipa, 2016). Salah satu metode yang dapat digunakan untuk menghitung $\mathrm{VaR}$ yaitu metode varians kovarians, dengan menggunakan nilai volatilitas (Damiyanti et al., 2018).

Volatilitas merupakan jarak fluktuasi pada return aset finansial, yang erat kaitannya dengan risiko (Danielsson, 2011). Kemungkinan risiko investasi pada suatu saham akan semakin besar apabila nilai volatilitasnya semakin besar (Maruddani and Purbowati, 2009). Terdapat beberapa model pendekatan yang dapat digunakan untuk memprediksi volatilitas seperti model autoregressive conditional heteroscedasticity (ARCH) yang diperkenalkan oleh Robert F. Engle pada tahun 1982, dan dapat digunakan untuk mengatasi keheterogenan varians. Model ARCH kurang efektif jika digunakan pada orde yang lebih tinggi sehingga pada tahun 1986 dikembangkan oleh Bollerslev menjadi model generalized autoregressive conditional heteroscedastisity (GARCH). Model ARCH dan GARCH memiliki respons volatilitas yang simetris terhadap good news dan bad news. Namun, pada beberapa data finansial terdapat respons volatilitas yang bersifat asimetris 
sehingga model GARCH dikembangkan lagi menjadi model GARCH asimetris yaitu model exponential GARCH (EGARCH) yang diperkenalkan oleh Nelson pada tahun 1991 dan model threshold GARCH (TGARCH) yang diperkenalkan oleh Zakoian pada tahun 1994.

Model GARCH, TGARCH, dan EGATCH banyak diterapkan oleh para peneliti untuk meramalkan volatilitas pada data finansial, seperti pada data harga saham. Puspitasari (2020) menyatakan bahwa investasi saham yang banyak diincar investor adalah investasi pada sektor perbankan, karena memiliki peran penting dalam pembangunan negara dan diawasi oleh Otoritas Jasa Keuangan (OJK). Terdapat beberapa saham yang merupakan saham unggulan atau saham blue chip yang banyak diminati investor dan tercatat sebagai saham utama pada papan pencatatan di Bursa Efek Indonesia (BEI) seperti BRI, BCA, dan Bank Mandiri. Agar dapat mengambil keputusan investasi yang tepat, maka perlu dilakukan perhitungan risiko terhadap saham tersebut. Oleh karena itu, tujuan dari penelitian ini adalah untuk melakukan peramalan volatilitas dan estimasi VaR dengan menggunakan model GARCH, TGARCH, atau EGARCH pada saham BRI, BCA, dan Bank Mandiri.

\section{METODE PENELITIAN}

Data yang digunakan dalam penelitian ini merupakan data sekunder yaitu data harga penutupan saham BRI, BCA, dan Bank Mandiri periode 25 Mei 2005 sampai 21 Mei 2021 selama hari aktif (Senin sampai Jumat) dengan jumlah data masing-masing saham yaitu 3.967 data yang diperoleh melalui website Yahoo Finance. Analisis data dilakukan dengan menggunakan software $R \quad 3.6 .2$ untuk meramalkan volatilitas dan software Excel 2007 untuk menghitung VaR. Adapun langkahlangkah analisis data dalam penelitian ini adalah sebagai berikut.

1. Menghitung Return

Nilai return dihitung berdasarkan persamaan (Tsay, 2013):

$$
r_{t}=\ln \left(\frac{P_{t}}{P_{t-1}}\right)=\ln P_{t}-\ln P_{t-1}
$$

dengan $P_{t}$ merupakan harga aset pada periode ke- $t$ serta $\ln$ adalah logaritma natural.

2. Analisis Deskriptif Data Return

Analisis deskriptif dilakukan untuk menegaskan secara empiris ciri khas dari data finansial dengan menghitung nilai skewness dan kurtosis.

3. Pemeriksaan Kestasioneran Data Return

Pemeriksaan kestasioneran data return dilakukan dengan mengamati plot data return, grafik correlogram ACF dan PACF data return, serta uji Augmented Dickey Fuller (ADF) dengan hipotesis uji yang digunakan yaitu (Tsay, 2013):

$$
\begin{aligned}
& H_{0}: \beta=0 \text { (data tidak stasioner) } \\
& H_{1}: \beta<0 \text { (data stasioner). }
\end{aligned}
$$

Statistik uji yang digunakan adalah:

$$
t_{p}=\frac{\widehat{\beta}-1}{S E(\widehat{\beta})}
$$

dengan $S E(\hat{\beta})$ merupakan standar error penduga $\beta$. Kriteria keputusan yang digunakan adalah hipotesis $H_{0}$ ditolak jika $\left|t_{p}\right|>Z_{\frac{\alpha}{2}}$ atau $p$-value $<\alpha$ (Tsay, 2013). Jika data return belum stasioner, maka dilakukan proses differencing hingga diperoleh data yang stasioner.

4. Pemeriksaan pada Return Kuadrat

Model GARCH, TGARCH, dan EGARCH baik diterapkan apabila terdapat korelasi serta efek ARCH pada return. Ada tidaknya autokorelasi dapat diketahui melalui uji Ljung-Box dengan hipotesis uji yang digunakan yaitu (Tsay, 2013):

$$
\begin{aligned}
& H_{0}: \rho_{1}=\rho_{2}=\ldots=\rho_{l}=0 \quad \text { (tidak } \\
& \quad \text { terdapat korelasi) } \\
& H_{1}: \exists \rho_{h} \neq 0 ; h=1,2,3, \ldots, l(\text { terdapat } \\
& \quad \text { korelasi), }
\end{aligned}
$$

serta statistik uji yang digunakan yaitu:

$$
Q(l)=T(T+2) \sum_{h=1}^{l} \frac{\widehat{\rho}_{h}^{2}}{T-h}
$$

dengan $l$ menyatakan banyaknya lag yang diuji dan $\hat{\rho}_{h}$ merupakan autokorelasi pada lag $h$. Kriteria keputusan yang digunakan adalah hipotesis $H_{0}$ ditolak jika $Q(l)>$ $\chi_{\alpha}^{2}$ atau jika nilai $p$-value $<\alpha$ (Tsay, 2013). Sedangkan ada tidaknya efek ARCH dapat diketahui melalui uji ARCH-Lagrange Multiplier (ARCH-LM) dengan hipotesis uji yang digunakan yaitu (Tsay, 2013):

$$
H_{0}: \alpha_{1}=\alpha_{2}=\alpha_{3}=\ldots=\alpha_{m}=0
$$$$
\text { (tidak terdapat efek ARCH) }
$$

$H_{1}: \exists \alpha_{i} \neq 0$ (terdapat efek ARCH).

Statistik uji yang digunakan yaitu:

$$
F=\frac{\left(S S R_{0}-S S R_{1}\right) / m}{S S R_{1} /(T-2 m-1)}
$$

dengan $\operatorname{SSR}_{0}=\sum_{t=m+1}^{T}\left(a_{t}^{2}-\bar{\omega}\right)^{2}, \quad \bar{\omega}=$ $(1 / T) \sum_{t=1}^{T} a_{t}^{2}$ merupakan mean dari $a_{t}^{2}$, dan $S S R_{1}=\sum_{t=m+1}^{T} \hat{e}_{t}^{2}$, dengan $\hat{e}_{t}^{2}$ merupakan residual kuadrat terkecil pada 
waktu $t$. kriteria keputusan yang digunakan adalah hipotesis $H_{0}$ ditolak jika nilai $F>$ $\chi_{m}^{2}(\alpha)$ atau $p$-value $<\alpha$ (Tsay, 2013). Jika tidak terdapat korelasi dan efek ARCH, maka proses berhenti atau tidak dimodelkan dengan model GARCH. Sedangkan jika terdapat korelasi dan efek $\mathrm{ARCH}$, maka proses dilanjutkan ke langkah 5.

5. Estimasi Parameter Model GARCH

Estimasi parameter model GARCH dilakukan dengan menggunakan data return dan software $R$.

6. Pemilihan Model GARCH

Model GARCH yang dipilih adalah model yang signifikan atau memiliki nilai $p$-value $<0,05$ berdasarkan estimasi parameter model GARCH pada langkah 5 dan memiliki nilai AIC terkecil. AIC dihitung berdasarkan rumus (Tsay, 2013):

$\mathrm{AIC}=-\frac{2}{T} \log ($ likelihood $)+2 \frac{\theta}{T}$.

7. Uji Sign dan Size Bias

Uji sign dan size bias dilakukan untuk mengetahui apakah terdapat efek asimetris pada data return. Adapun hipotesis uji yang digunakan yaitu (Tsay, 2013):

$$
\begin{aligned}
& H_{0}: \varphi_{1}=\varphi_{2}=\varphi_{3}=\ldots=\varphi_{m}=0 \\
& \text { (residual bersifat simetris) } \\
& H_{1}: \exists \varphi_{i} \neq 0 ; i=1,2,3, \ldots, m \\
& \text { (residual bersifat asimetris). }
\end{aligned}
$$

Sedangkan statistik uji yang digunakan yaitu:

$$
F=\frac{S S R_{0} / k}{S S R_{1} /(T-k-1)} .
$$

Kriteria keputusan yang digunakan adalah hipotesis $H_{0}$ ditolak jika nilai $F>\chi_{m}^{2}(\alpha)$ atau $p$-value $<\alpha$ (Tsay, 2013). Jika tidak terdapat efek asimetris, maka volatilitas dimodelkan dengan menggunakan model GARCH. Persamaan model $\operatorname{GARCH}(m, s)$ yaitu (Tsay, 2013):

$\sigma_{t}^{2}=\alpha_{0}+\sum_{i=1}^{m} \alpha_{i} a_{t-i}^{2}+\sum_{j=1}^{s} \beta_{j} \sigma_{t-j}^{2}$. (7)

Jika terdapat efek asimetris, maka dilanjutkan ke langkah 8.

8. Estimasi Parameter Model TGARCH dan EGARCH

Estimasi parameter model TGARCH dan EGARCH dilakukan menggunakan data return dan software $R$. Persamaan model $\operatorname{EGARCH}(m, s)$ yaitu (Tsay, 2013):

$$
\begin{gathered}
\ln \left(\sigma_{t}^{2}\right)=\alpha_{0}+\sum_{i=1}^{m} \alpha_{i} \frac{\left|a_{t-1}\right|+\gamma_{i} a_{t-i}}{\sigma_{(t-i)}}+ \\
\sum_{i=1}^{s} \beta_{j} \ln \left(\sigma_{t-j}^{2}\right)
\end{gathered}
$$

dengan $\gamma_{i}$ merupakan parameter leverage effect $a_{t-i}$. Sedangkan persamaan model $\operatorname{TGARCH}(m, s)$ yaitu (Tsay, 2013):

$$
\begin{aligned}
\sigma_{t}^{2}= & \alpha_{0}+\sum_{i=1}^{m}\left(\alpha_{i}+\gamma_{i} N_{t-i}^{2}\right) a_{t-i}^{2}+ \\
& \sum_{j=1}^{s} \beta_{j} \sigma_{t-j}^{2}
\end{aligned}
$$

dengan $N_{t-i}^{-}$merupakan indikator dari $a_{t-i}$ negatif atau disebut juga variabel dummy yaitu:

$$
N_{t-i}^{-}=\left\{\begin{array}{l}
1 ; \text { jika } a_{t-i}<0 \\
0 ; \text { jika } a_{t-i} \geq 0
\end{array} .\right.
$$

9. Peramalan Volatilitas

Peramalan volatilitas dilakukan pada empat belas periode berikutnya yaitu 24 Mei 2021 sampai 10 Juni 2021 dengan menggunakan model yang terpilih.

10. Estimasi Value at Risk (VaR)

Estimasi VaR dilakukan dengan menggunakan holding period satu hari, tingkat kepercayaan 95\%, dan diasumsikan investasi awal yang digunakan yaitu Rp10.000.000,00. Persamaan yang digunakan untuk menghitung VaR yaitu (Jorion, 2007):

$\operatorname{VaR}=W_{0} \cdot\left(Z_{\alpha} \cdot \sqrt{k} \cdot \sigma\right)$

dengan $W_{0}$ merupakan investasi awal, $Z_{\alpha}$ merupakan kuantil distribusi normal standar, $\sigma$ merupakan volatilitas, dan $k$ merupakan holding period.

\section{HASIL DAN PEMBAHASAN}

\subsection{Menghitung Return}

Tabel 1. Data Pertama dan Kedua Harga Penutupan Saham BRI, BCA, dan Bank Mandiri

\begin{tabular}{|l|c|c|c|}
\hline & $\begin{array}{c}\text { BRI } \\
(\mathrm{Rp})\end{array}$ & $\begin{array}{c}\text { BCA } \\
(\mathrm{Rp})\end{array}$ & $\begin{array}{c}\text { Bank } \\
\text { Mandiri } \\
(\mathrm{Rp})\end{array}$ \\
\hline $\begin{array}{l}\text { Data } \\
\text { Pertama }\end{array}$ & 275 & $1.637,5$ & 830,89 \\
\hline $\begin{array}{l}\text { Data } \\
\text { Kedua }\end{array}$ & 280 & 1.650 & 830,89 \\
\hline
\end{tabular}

Sumber: Data diolah, 2021

Data Return dihitung dengan menggunakan persamaan (1). Berdasarkan Tabel 1 serta dengan memisalkan $r_{i A}, r_{i B}, r_{i C}$ secara berturutturut merupakan return ke- $i$ saham BRI, BCA, dan Bank Mandiri, maka contoh perhitungan nilai return pertama saham BRI, BCA, dan Bank Mandiri yaitu:

$$
\begin{aligned}
& r_{1 A}=\ln \frac{280}{275}=0,018, \\
& r_{1 B}=\ln \frac{1.650}{1.637,5}=0,007, \text { dan }
\end{aligned}
$$


$r_{1 C}=\ln \frac{830,891479}{830,891479}=0$.

Dengan cara yang sama, dapat dihitung nilai return untuk $t=2,3,4, \ldots, 3.967$ dari masingmasing saham.

\subsection{Analisis Desk riptif Data Return}

Statistika deskriptif data return BRI, BCA, dan Bank Mandiri dapat dilihat pada Tabel 2.

Tabel 2. Statistika Deskriptif Data Return BRI, BCA, dan Bank Mandiri

\begin{tabular}{|c|c|c|c|}
\hline $\begin{array}{c}\text { Statistika } \\
\text { Deskriptif }\end{array}$ & $\begin{array}{c}\text { Return } \\
\text { BRI }\end{array}$ & $\begin{array}{c}\text { Return } \\
\text { BCA }\end{array}$ & $\begin{array}{c}\text { Return Bank } \\
\text { Mandiri }\end{array}$ \\
\hline Minimum & $-0,140582$ & $-0,106222$ & $-0,156842$ \\
\hline Maksimum & 0,186412 & 0,159849 & 0,182322 \\
\hline Rata-rata & 0,000668 & 0,000748 & 0,000491 \\
\hline $\begin{array}{c}\text { Deviasi } \\
\text { Standar }\end{array}$ & 0,024912 & 0,019424 & 0,024827 \\
\hline Skewness & 0,330636 & 0,079374 & 0,228580 \\
\hline Kurtosis & 4,549173 & 4,910327 & 5,053740 \\
\hline
\end{tabular}

Sumber: Data diolah, 2021

Berdasarkan Tabel 2 diketahui saham Bank Mandiri memiliki nilai return minimum paling rendah dibandingkan saham lainnya dan saham BRI memiliki nilai return maksimum paling tinggi dibandingkan saham lainnya. Nilai ratarata return dari masing-masing saham bernilai positif yang menunjukkan adanya peluang mendapatkan keuntungan. Nilai deviasi standar return saham BRI, BCA, dan Bank Mandiri tidak sama dengan nol yang menunjukkan bahwa setiap data pada masing-masing saham tidak sama atau terdapat kecenderungan setiap data berbeda (heterogen). Nilai skewness masing-masing saham lebih besar dari nol menunjukkan distribusi dari return memiliki ekor kanan lebih panjang daripada ekor kiri distribusinya. Hal ini berarti terdapat adanya ketidaksimetrisan pada data. Kemudian nilai kurtosis masing-masing saham lebih dari tiga yang menunjukkan adanya excess kurtosis sehingga diketahui bahwa return dari ketiga saham tidak berdistribusi normal yang merupakan stylized fact return data finansial.

\subsection{Pemeriksaan Kestasioneran Data Return}

Pemeriksaan kestasioneran melalui plot data return dapat dilihat secara berturut-turut pada Gambar 1, 2, dan 3.

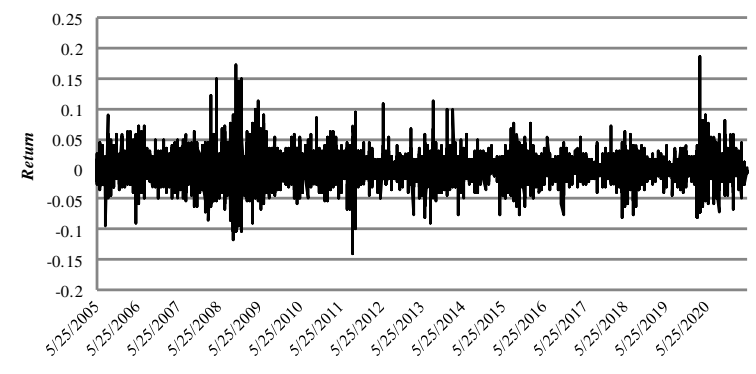

Gambar 1. Plot Data Return BRI

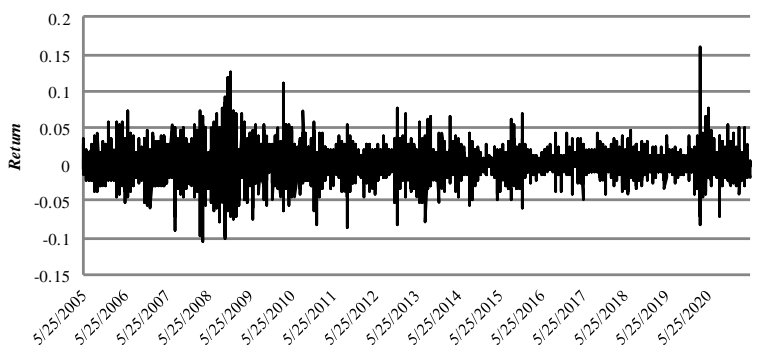

Gambar 2. Plot Data Return BCA

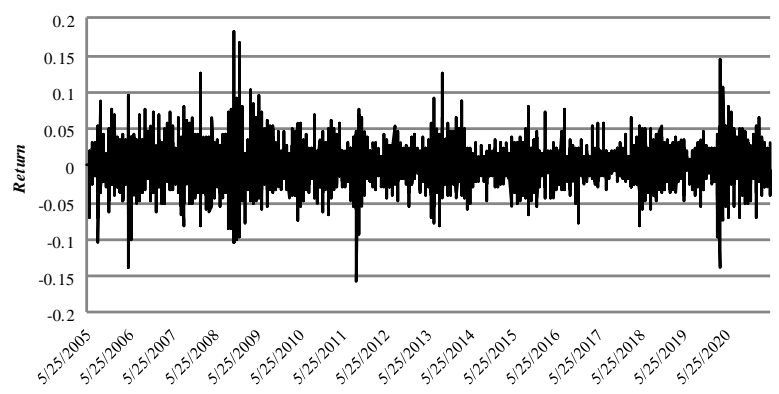

Gambar 3. Plot Data Return Bank Mandiri

Berdasarkan Gambar 1, 2, dan 3 dapat diamati bahwa data return BRI, BCA, dan Bank Mandiri sangat fluktuatif dari waktu ke waktu serta menunjukkan adanya volatility clustering. Berdasarkan plot data return di atas, dapat diperkirakan bahwa data return stasioner dalam mean karena return bergerak pada kisaran nilai mean. Pemeriksaan kestasioneran terhadap data return juga dapat diamati melalui grafik correlogram nilai ACF dan PACF yang dapat dilihat pada Gambar 4, 5, dan 6. 
Tabel 3 Hasil Uji ADF
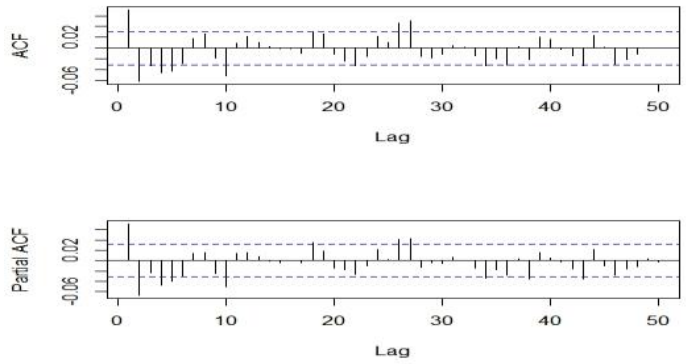

Gambar 4. Grafik Correlogram Nilai ACF dan PACF Data Return BRI

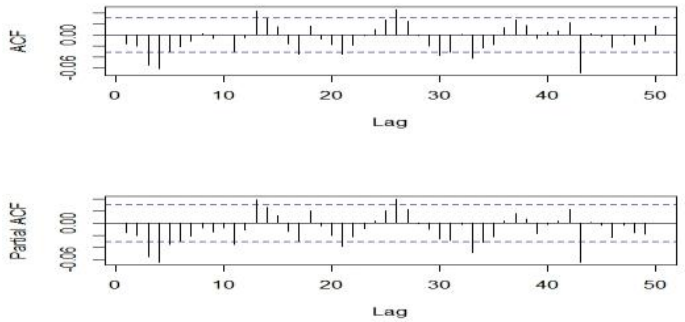

Gambar 5. Grafik Correlogram Nilai ACF dan PACF Data Return BCA
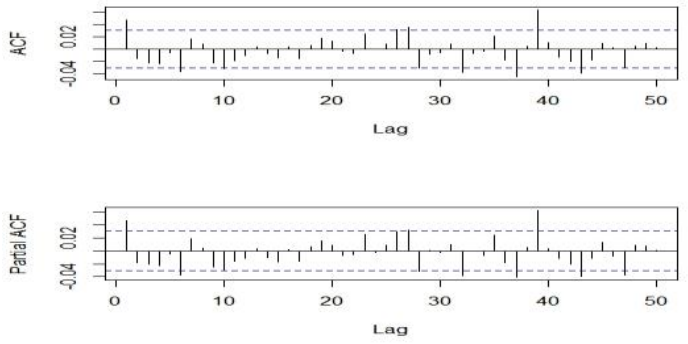

Gambar 6. Grafik Correlogram Nilai ACF dan PACF Data Return Bank Mandiri

Berdasarkan Gambar 4, 5, dan 6 dapat diamati bahwa hanya beberapa lag yang keluar dari garis Bartlett sehingga mengindikasikan data return sudah stasioner. Namun untuk lebih memastikan bahwa data return sudah stasioner, maka dilakukan uji ADF. Adapun hasil uji ADF dengan menggunakan statistik uji pada persamaan (2) dapat dilihat pada Tabel 3.

\begin{tabular}{|c|c|c|c|}
\hline & $\begin{array}{c}\text { Return } \\
\text { BRI }\end{array}$ & $\begin{array}{c}\text { Return } \\
\text { BCA }\end{array}$ & $\begin{array}{c}\text { Return Bank } \\
\text { Mandiri }\end{array}$ \\
\hline$p$-value & 0,01 & 0,01 & 0,01 \\
\hline
\end{tabular}

Sumber: Data diolah, 2021

Berdasarkan Tabel 3 diketahui return masingmasing saham memiliki nilai $p$-value sebesar 0,01 . Hal ini berarti data return saham BRI, BCA, dan Bank Mandiri sudah stasioner.

\subsection{Pemeriksaan Return Kuadrat}

Ada tidaknya autokorelasi dapat diketahui melalui uji Ljung-Box dengan menggunakan statistik uji pada persamaan (3). Sedangkan ada tidaknya efek ARCH, dapat diketahui melalui uji ARCH-LM dengan menggunakan statistik uji pada persamaan (4). Dengan menggunakan software $R$, diperoleh nilai $Q$ dan nilai $F$ yang disajikan pada Tabel 4 .

Tabel 4. Hasil Uji Ljung-Box dan Uji ARCH$\mathrm{LM}$

\begin{tabular}{|c|c|c|c|}
\hline Uji & BRI & \multicolumn{1}{c|}{ BCA } & $\begin{array}{c}\text { Bank } \\
\text { Mandiri }\end{array}$ \\
\hline$Q$ & $2,2 \times 10^{-16}$ & $2,2 \times 10^{-16}$ & $2,2 \times 10^{-16}$ \\
\hline$F$ & $2,2 \times 10^{-16}$ & $5,764 \times 10^{-12}$ & $2,2 \times 10^{-16}$ \\
\hline
\end{tabular}

Sumber: Data diolah, 2021

Tabel 4 menunjukkan hasil uji Ljung-Box dengan taraf signifikansi 5\% masing-masing saham memiliki nilai $p$-value $2,2 \times 10^{-16}$ sehingga tidak cukup bukti untuk menerima $H_{0}$. Sehingga, dapat disimpulkan terdapat korelasi pada masing-masing saham. Uji ARCH-LM dari masing-masing saham menghasilkan nilai $p$-value $<0,05$ yang berarti tidak cukup bukti untuk menerima $H_{0}$. Dengan demikian berarti terdapat efek ARCH pada data return kuadrat saham BRI, BCA, dan Bank Mandiri. Karena terdapat korelasi dan efek $\mathrm{ARCH}$, maka volatilitas dimodelkan dengan menggunakan model GARCH.

\subsection{Estimasi Paramater Model GARCH}

Estimasi parameter model GARCH $(m, s)$ dilakukan dengan menggunakan software $R$ dan data return. Adapun hasil estimasi parameter model GARCH untuk masing-masing saham dapat diamati melalui Tabel 5, 6, dan 7. 
Tabel 5. Estimasi Parameter Model $\operatorname{GARCH}(m, s)$ Saham BRI

\begin{tabular}{|c|c|c|r|}
\hline Model & $\begin{array}{c}\text { Para } \\
\text { meter }\end{array}$ & $\begin{array}{c}\text { Estimasi } \\
\text { Parameter }\end{array}$ & \multicolumn{1}{|c|}{-value } \\
\hline GARCH(1,1) & $\alpha_{0}$ & $1,208 \times 10^{-5}$ & $6,33 \times 10^{-8}$ \\
& $\alpha_{1}$ & $9,260 \times 10^{-2}$ & $2 \times 10^{-16}$ \\
& $\beta_{1}$ & $8,885 \times 10^{-1}$ & $2 \times 10^{-16}$ \\
\hline GARCH(1,2) & $\alpha_{0}$ & $1,620 \times 10^{-5}$ & $9,54 \times 10^{-8}$ \\
& $\alpha_{1}$ & $1,288 \times 10^{-1}$ & $2,22 \times 10^{-16}$ \\
& $\beta_{1}$ & $4,173 \times 10^{-1}$ & 0,000161 \\
& $\beta_{2}$ & $4,287 \times 10^{-1}$ & $2,49 \times 10^{-5}$ \\
\hline GARCH(2,1) & $\alpha_{0}$ & $1,207 \times 10^{-5}$ & $1,65 \times 10^{-6}$ \\
& $\alpha_{1}$ & $9,257 \times 10^{-2}$ & $2,94 \times 10^{-8}$ \\
& $\alpha_{2}$ & $1 \times 10^{-8}$ & 1 \\
& $\beta_{1}$ & $8,885 \times 10^{-1}$ & $2 \times 10^{-16}$ \\
\hline GARCH(2,2) & $\alpha_{0}$ & $1,620 \times 10^{-5}$ & 0,013090 \\
& $\alpha_{1}$ & $1,288 \times 10^{-1}$ & $2,67 \times 10^{-8}$ \\
& $\alpha_{2}$ & $1 \times 10^{-8}$ & 1 \\
& $\beta_{1}$ & $4,173 \times 10^{-1}$ & 0,283007 \\
& $\beta_{2}$ & $4,287 \times 10^{-1}$ & 0,203660 \\
\hline
\end{tabular}

Sumber: Data diolah, 2021

Tabel 6. Estimasi Parameter Model

$\operatorname{GARCH}(m, s)$ Saham BCA

\begin{tabular}{|c|c|r|r|}
\hline Model & $\begin{array}{c}\text { Para } \\
\text { meter }\end{array}$ & $\begin{array}{c}\text { Estimasi } \\
\text { Parameter }\end{array}$ & \multicolumn{1}{c|}{-value } \\
\hline GARCH(1,1) & $\alpha_{0}$ & $6,279 \times 10^{-6}$ & $1,10 \times 10^{-5}$ \\
& $\alpha_{1}$ & $8,469 \times 10^{-2}$ & $2,04 \times 10^{-14}$ \\
& $\beta_{1}$ & $8,995 \times 10^{-1}$ & $2 \times 10^{-16}$ \\
\hline GARCH(1,2) & $\alpha_{0}$ & $8,190 \times 10^{-6}$ & $8,65 \times 10^{-6}$ \\
& $\alpha_{1}$ & $1,136 \times 10^{-1}$ & $9,77 \times 10^{-15}$ \\
& $\beta_{1}$ & $4,514 \times 10^{-1}$ & $5,62 \times 10^{-6}$ \\
& $\beta_{2}$ & $4,139 \times 10^{-1}$ & $9,35 \times 10^{-6}$ \\
\hline GARCH(2,1) & $\alpha_{0}$ & $6,303 \times 10^{-6}$ & 0,000673 \\
& $\alpha_{1}$ & $8,487 \times 10^{-2}$ & $4,47 \times 10^{-10}$ \\
& $\alpha_{2}$ & $1 \times 10^{-8}$ & 1 \\
& $\beta_{1}$ & $8,992 \times 10^{-1}$ & $2 \times 10^{-16}$ \\
\hline GARCH(2,2) & $\alpha_{0}$ & $8,190 \times 10^{-6}$ & NA \\
& $\alpha_{1}$ & 10,746 & $2 \times 10^{-16}$ \\
& $\alpha_{2}$ & $1 \times 10^{-8}$ & NA \\
& $\beta_{1}$ & $4,514 \times 10^{-1}$ & NA \\
& $\beta_{2}$ & $4,139 \times 10^{-1}$ & NA \\
\hline
\end{tabular}

Sumber: Data diolah, 2021

Tabel 7. Estimasi Parameter Model $\operatorname{GARCH}(m, s)$ Saham Bank Mandiri

\begin{tabular}{|c|c|r|r|}
\hline Model & $\begin{array}{c}\text { Para } \\
\text { meter }\end{array}$ & $\begin{array}{c}\text { Estimasi } \\
\text { Parameter }\end{array}$ & \multicolumn{1}{|c|}{-value } \\
\hline GARCH(1,1) & $\alpha_{0}$ & $1,815 \times 10^{-5}$ & $5,07 \times 10^{-6}$ \\
& $\alpha_{1}$ & $1,019 \times 10^{-1}$ & $2,22 \times 10^{-16}$ \\
& $\beta_{1}$ & $8,676 \times 10^{-1}$ & $2 \times 10^{-16}$ \\
\hline GARCH(1,2) & $\alpha_{0}$ & $2,378 \times 10^{-5}$ & $2,15 \times 10^{-6}$ \\
& $\alpha_{1}$ & $1,394 \times 10^{-1}$ & $2 \times 10^{-16}$ \\
& $\beta_{1}$ & $3,761 \times 10^{-1}$ & $3,32 \times 10^{-5}$ \\
& $\beta_{2}$ & $4,442 \times 10^{-1}$ & $1,24 \times 10^{-7}$ \\
\hline GARCH(2,1) & $\alpha_{0}$ & $1,820 \times 10^{-5}$ & 0,000256 \\
& $\alpha_{1}$ & $1,021 \times 10^{-1}$ & $6,091 \times 0^{-10}$ \\
& $\alpha_{2}$ & $1 \times 10^{-8}$ & 1 \\
& $\beta_{1}$ & $8,673 \times 10^{-1}$ & $2 \times 10^{-16}$ \\
\hline GARCH(2,2) & $\alpha_{0}$ & $2,378 \times 10^{-5}$ & 0,00153 \\
& $\alpha_{1}$ & $1,394 \times 10^{-1}$ & $3,26 \times 10^{-12}$ \\
& $\alpha_{2}$ & $1 \times 10^{-8}$ & 1 \\
& $\beta_{1}$ & $3,761 \times 10^{-1}$ & 0,06011 \\
& $\beta_{2}$ & $4,442 \times 10^{-1}$ & 0,00700 \\
\hline
\end{tabular}

Sumber: Data diolah, 2021

\subsection{Pemilihan Model GARCH}

Pemilihan model GARCH dilakukan dengan memilih model yang signifikan dan memiliki nilai AIC terkecil. Nilai AIC dihitung dengan menggunakan persamaan (5) dan menggunakan software $R$. Berdasarkan hasil estimasi parameter model GARCH pada subbab sebelumnya, diketahui hanya model $\operatorname{GARCH}(1,1)$ dan $\operatorname{GARCH}(1,2)$ yang signifikan karena memiliki nilai $p$-value $<0,05$. Oleh karena itu, perhitungan nilai AIC hanya dilakukan terhadap model tersebut. Adapun nilai AIC return saham BRI, BCA, dan Bank Mandiri secara berturut-turut dapat dilihat pada Tabel 8,9, dan 10.

Tabel 8. Nilai AIC Model GARCH $(m, s)$ Data Return BRI

\begin{tabular}{|c|c|}
\hline Model & AIC \\
\hline GARCH(1,1) & $-4,800689$ \\
\hline GARCH(1,2) & $\mathbf{- 4 , 8 0 2 3 9 0}$ \\
\hline
\end{tabular}

Sumber: Data diolah, 2021

Tabel 9. Nilai AIC Model $\operatorname{GARCH}(m, s)$ Data Return BCA

\begin{tabular}{|c|c|}
\hline Model & AIC \\
\hline GARCH $(1,1)$ & $-5,297732$ \\
\hline GARCH(1,2) & $\mathbf{- 5 , 3 0 0 4 6 2}$ \\
\hline
\end{tabular}

Sumber: Data diolah, 2021

Tabel 10. Nilai AIC Model GARCH $(m, s)$ Data Return Bank Mandiri

\begin{tabular}{|c|c|}
\hline Model & AIC \\
\hline GARCH(1,1) & $-4,796578$ \\
\hline GARCH(1,2) & $\mathbf{- 4 , 7 9 9 4 3 6}$ \\
\hline
\end{tabular}

Sumber: Data diolah, 2021

Tabel 8, 9, dan 10 menunjukkan bahwa nilai AIC terkecil di antara model GARCH yang ditinjau untuk saham BRI, BCA, dan Bank Mandiri adalah model $\operatorname{GARCH}(1,2)$. Oleh karena itu, model yang dipilih di sini adalah model GARCH $(1,2)$. Adapun persamaan model $\operatorname{GARCH}(1,2)$ saham BRI, BCA, dan Bank Mandiri berdasarkan model GARCH pada persamaan (7) dan nilai parameter $\alpha_{0}, \alpha_{1}, \beta_{1}$, dan $\beta_{2}$ model $\operatorname{GARCH}(1,2)$ pada Tabel 5, 6, dan 7 secara berturut-turut adalah:

$$
\begin{gathered}
\sigma_{t A}^{2}=0,0000162+0,1288 a_{t-1}^{2}+ \\
0,4173 \sigma_{t-1}^{2}+-0,4287 \sigma_{t-2}^{2} \\
\sigma_{t B}^{2}=0,00000819+0,1136 a_{t-1}^{2}+ \\
0,4514 \sigma_{t-1}^{2}+0,4139 \sigma_{t-2}^{2}
\end{gathered}
$$




$$
\begin{aligned}
\sigma_{t C}^{2}= & 0,00002378+0,1394 a_{t-1}^{2}+ \\
& 0,3761 \sigma_{t-1}^{2}+0,4442 \sigma_{t-2}^{2} .
\end{aligned}
$$

\subsection{Uji Sign dan Size Bias}

Uji sign dan size bias dilakukan dengan menggunakan statistik uji pada persamaan (6) dan dengan menggunakan software $R$. Adapun hasil uji sign dan size bias dari model $\operatorname{GARCH}(1,2)$ saham BRI, BCA, dan Bank Mandiri dapat dilihat pada Tabel 11,12, dan 13.

Tabel 11. Uji Sign dan Size Bias Model $\operatorname{GARCH}(1,2)$ Saham BRI

\begin{tabular}{|c|c|c|c|}
\hline & t-statistic & $p$-value & Sig \\
\hline Sign Bias & 1,2943314 & 0,1956264 & \\
\hline $\begin{array}{c}\text { Negative } \\
\text { Size Bias }\end{array}$ & 0,2736724 & 0,7843507 & \\
\hline $\begin{array}{c}\text { Positive } \\
\text { Size Bias }\end{array}$ & 0,8351571 & 0,4036796 & \\
\hline Join Effect & 2,5962503 & 0,4581473 & \\
\hline
\end{tabular}

Sumber:Data diolah, 2021

Tabel 12. Uji Sign dan Size Bias Model GARCH(1,2) Saham BCA

\begin{tabular}{|c|c|c|r|}
\hline & $t$-statistic & p-value & Sig \\
\hline Sign Bias & 1,9022245 & 0,05721428 & $*$ \\
\hline $\begin{array}{l}\text { Negative } \\
\text { Size Bias }\end{array}$ & 0,8734421 & 0,38247508 & \\
\hline $\begin{array}{c}\text { Positive } \\
\text { Size Bias }\end{array}$ & 1,2010190 & 0,22981564 & \\
\hline Join Effect & 7,0619783 & 0,06994833 & $*$ \\
\hline
\end{tabular}

Sumber:Data diolah, 2021

Tabel 13. Uji Sign dan Size Bias Model $\operatorname{GARCH}(1,2)$ Saham Bank Mandiri

\begin{tabular}{|c|c|c|c|}
\hline & $t$-statistic & $p$-value & Sig \\
\hline Sign Bias & 1,03804872 & 0,29931073 & \\
\hline $\begin{array}{l}\text { Negative } \\
\text { Size Bias }\end{array}$ & 1,80547981 & 0,07107553 & $*$ \\
\hline $\begin{array}{c}\text { Positive } \\
\text { Size Bias }\end{array}$ & 0,05908017 & 0,95289123 & \\
\hline Join Effect & 9,40678344 & 0,02434399 & $* *$ \\
\hline
\end{tabular}

Sumber:Data diolah, 2021

Tabel 11 menunjukkan saham BRI tidak bersifat asimetris karena tidak terdapat parameter dari uji sign dan size bias yang signifikan. Sehingga peramalan volatilitas saham BRI dimodelkan dengan menggunakan model $\operatorname{GARCH}(1,2)$. Hasil uji sign dan size bias saham BCA pada Tabel 12 menunjukkan parameter sign bias signifikan, serta uji sign dan size bias saham Bank Mandiri pada Tabel 13 menunjukkan bahwa parameter negative size bias signifikan. Oleh karena itu, volatilitas saham BCA dan Bank Mandiri dimodelkan dengan menggunakan model GARCH asimetris.

\subsection{Estimasi Parameter Model TGARCH dan EGARCH}

Estimasi parameter model TGARCH dan EGARCH dilakukan dengan menggunakan software $R$ dan data return. Adapun hasil estimasi parameter model TGARCH dan EGARCH data return saham BCA dan Bank Mandiri dapat diamati melalui Tabel 14 dan 15.

Tabel 14. Estimasi Parameter Model EGARCH

\begin{tabular}{|c|c|c|c|}
\hline Model & $\begin{array}{l}\text { Parame } \\
\text { ter }\end{array}$ & Estimasi Parameter & p-value \\
\hline EGARCH(1,1) & $\begin{array}{l}\alpha_{0} \\
\alpha_{1} \\
\beta_{1} \\
\gamma_{1} \\
\end{array}$ & $\begin{array}{r}-0,209030 \\
-0,043150 \\
0,972625 \\
0,174414 \\
\end{array}$ & $\begin{array}{r}0 \\
0,000006 \\
0 \\
0\end{array}$ \\
\hline$\overline{\text { EGARCH(1,2) }}$ & $\begin{array}{l}\alpha_{0} \\
\alpha_{1} \\
\beta_{1} \\
\beta_{2} \\
\gamma_{1} \\
\end{array}$ & $\begin{array}{r}-0,271973 \\
-0,056156 \\
0,544845 \\
0,419495 \\
0,236644 \\
\end{array}$ & $\begin{array}{r}0,016275 \\
0 \\
0 \\
0 \\
0 \\
\end{array}$ \\
\hline EGARCH $(2,1)$ & $\begin{array}{l}\alpha_{0} \\
\alpha_{1} \\
\alpha_{2} \\
\beta_{1} \\
\gamma_{1} \\
\gamma_{2}\end{array}$ & $\begin{array}{r}-0,144013 \\
-0,038693 \\
-0,002572 \\
0,981054 \\
0,303212 \\
-0,166389\end{array}$ & $\begin{array}{r}0 \\
0,071278 \\
0,904616 \\
0 \\
0 \\
0\end{array}$ \\
\hline EGARCH $(2,2)$ & $\begin{array}{l}\alpha_{0} \\
\alpha_{1} \\
\alpha_{2} \\
\beta_{1} \\
\beta_{2} \\
\gamma_{1} \\
\gamma_{2} \\
\end{array}$ & $\begin{array}{r}-0,140772 \\
-0,038776 \\
-0,001591 \\
0,999990 \\
-0,018512 \\
0,303848 \\
-0,169948 \\
\end{array}$ & $\begin{array}{r}0 \\
0,063581 \\
0,940888 \\
0 \\
0 \\
0 \\
0,001500 \\
\end{array}$ \\
\hline TGARCH(1,1) & $\begin{array}{l}\alpha_{0} \\
\alpha_{1} \\
\beta_{1} \\
\gamma_{1}\end{array}$ & $\begin{array}{l}4,890 \times 10^{-4} \\
9,047 \times 10^{-2} \\
9,085 \times 10^{-1} \\
3,041 \times 10^{-1} \\
\end{array}$ & $\begin{array}{r}2,85 \times 10^{-10} \\
2 \times 10^{-16} \\
2 \times 10^{-16} \\
1,92 \times 10^{-7} \\
\end{array}$ \\
\hline TGARCH(1,2) & $\begin{array}{l}\alpha_{0} \\
\alpha_{1} \\
\beta_{1} \\
\beta_{2} \\
\gamma_{1}\end{array}$ & $\begin{array}{l}0,0006368 \\
0,1205156 \\
0,4738161 \\
0,4049610 \\
0,3083516 \\
\end{array}$ & $\begin{array}{r}2,98 \times 10^{-10} \\
2 \times 10^{-16} \\
5,57 \times 10^{-7} \\
6,25 \times 10^{-6} \\
6,49 \times 10^{-8}\end{array}$ \\
\hline TGARCH $(2,1)$ & $\begin{array}{l}\alpha_{0} \\
\alpha_{1} \\
\alpha_{2} \\
\beta_{1} \\
\gamma_{1} \\
\gamma_{2}\end{array}$ & $\begin{array}{r}4,901 \times 10^{-4} \\
9,058 \times 10^{-2} \\
1 \times 10^{-8} \\
9,084 \times 10^{-1} \\
3,039 \times 10^{-1} \\
3,340 \times 10^{-1} \\
\end{array}$ & $\begin{array}{r}2,86 \times 10^{-10} \\
2 \times 10^{-16} \\
\mathrm{NA} \\
2 \times 10^{-16} \\
1,93 \times 10^{-7} \\
\mathrm{NA}\end{array}$ \\
\hline TGARCH $(2,2)$ & $\begin{array}{l}\alpha_{0} \\
\alpha_{1} \\
\alpha_{2} \\
\beta_{1} \\
\beta_{2} \\
\gamma_{1} \\
\gamma_{2}\end{array}$ & $\begin{array}{r}6,367 \times 10^{-4} \\
1,205 \times 10^{-1} \\
1 \times 10^{-8} \\
4,738 \times 10^{-1} \\
4,050 \times 10^{-1} \\
3,084 \times 10^{-1} \\
2,653 \times 10^{-1} \\
\end{array}$ & $\begin{array}{r}2,98 \times 10^{-10} \\
2 \times 10^{-16} \\
\mathrm{NA} \\
5,57 \times 10^{-7} \\
6,25 \times 10^{-6} \\
6,49 \times 10^{-8} \\
\mathrm{NA} \\
\end{array}$ \\
\hline
\end{tabular}
dan TGARCH Return BCA

Sumber: Data diolah, 2021 
Tabel 15. Estimasi Parameter Model EGARCH dan TGARCH Data Return Saham Bank Mandiri

\begin{tabular}{|c|c|c|c|}
\hline Model & $\begin{array}{l}\text { Para } \\
\text { meter }\end{array}$ & Estimasi Parameter & $p$-value \\
\hline EGARCH(1,1) & $\begin{array}{l}\alpha_{0} \\
\alpha_{1} \\
\beta_{1} \\
\gamma_{1}\end{array}$ & $\begin{array}{r}-0,240873 \\
-0,044513 \\
0,967064 \\
0,177182\end{array}$ & $\begin{array}{r}0 \\
0,000017 \\
0 \\
0,000006\end{array}$ \\
\hline EGARCH(1,2) & $\begin{array}{l}\alpha_{0} \\
\alpha_{1} \\
\beta_{1} \\
\beta_{2} \\
\gamma_{1}\end{array}$ & $\begin{array}{r}-0,307281 \\
-0,062306 \\
0,507072 \\
0,450842 \\
0,237967\end{array}$ & $\begin{array}{r}0,004190 \\
0 \\
0 \\
0 \\
0\end{array}$ \\
\hline EGARCH $(2,1)$ & $\begin{array}{l}\alpha_{0} \\
\alpha_{1} \\
\alpha_{2} \\
\beta_{1} \\
\gamma_{1} \\
\gamma_{2}\end{array}$ & $\begin{array}{r}-0,167975 \\
-0.069838 \\
0,028018 \\
0,976913 \\
0,274321 \\
-0,133026\end{array}$ & $\begin{array}{r}0 \\
0,001501 \\
0,208789 \\
0 \\
0 \\
0\end{array}$ \\
\hline EGARCH $(2,2)$ & $\begin{array}{l}\alpha_{0} \\
\alpha_{1} \\
\alpha_{2} \\
\beta_{1} \\
\beta_{2} \\
\gamma_{1} \\
\gamma_{2}\end{array}$ & $\begin{array}{r}-0,163675 \\
-0,070255 \\
0,029459 \\
1 \\
-0,022495 \\
0,274859 \\
-0,137203\end{array}$ & $\begin{array}{r}0 \\
0,001403 \\
0,192709 \\
0 \\
0 \\
0 \\
0,000031\end{array}$ \\
\hline TGARCH(1,1) & $\begin{array}{l}\alpha_{2} \\
\alpha_{1} \\
\beta_{1} \\
\gamma_{1}\end{array}$ & $\begin{array}{l}0,0008483 \\
0,0959997 \\
0,8926063 \\
0,2923670\end{array}$ & $\begin{array}{r}1,2 \times 10^{-6} \\
2 \times 10^{-16} \\
2 \times 10^{-16} \\
1,4 \times 10^{-7}\end{array}$ \\
\hline TGARCH(1,2) & $\begin{array}{l}\alpha_{0} \\
\alpha_{1} \\
\beta_{1} \\
\beta_{2} \\
\gamma_{1}\end{array}$ & $\begin{array}{l}0,001068 \\
0,128751 \\
0,388240 \\
0,470613 \\
0,297978\end{array}$ & $\begin{array}{r}2,18 \times 10^{-7} \\
2 \times 10^{-16} \\
6,84 \times 10^{-5} \\
5,92 \times 10^{-7} \\
1,38 \times 10^{-7}\end{array}$ \\
\hline TGARCH $(2,1)$ & $\begin{array}{l}\alpha_{0} \\
\alpha_{1} \\
\alpha_{2} \\
\beta_{1} \\
\gamma_{1} \\
\gamma_{2}\end{array}$ & $\begin{array}{r}8,5231 \times 10^{-4} \\
9,626 \times 10^{-2} \\
1 \times 10^{-8} \\
8,922 \times 10^{-1} \\
2,912 \times 10^{-1} \\
1,457 \times 10^{-1}\end{array}$ & $\begin{array}{r}1,12 \times 10^{-6} \\
2 \times 10^{-16} \\
\mathrm{NA} \\
2 \times 10^{-16} \\
1,51 \times 10^{-7} \\
\mathrm{NA}\end{array}$ \\
\hline TGARCH $(2,2)$ & $\begin{array}{l}\alpha_{0} \\
\alpha_{1} \\
\alpha_{2} \\
\beta_{1} \\
\beta_{2} \\
\gamma_{1} \\
\gamma_{2}\end{array}$ & $\begin{array}{r}1,068 \times 10^{-3} \\
1,288 \times 10^{-1} \\
1 \times 10^{-8} \\
3,882 \times 10^{-1} \\
4,706 \times 10^{-1} \\
2,980 \times 10^{-1} \\
8,474 \times 10^{-2}\end{array}$ & $\begin{array}{r}2,18 \times 10^{-7} \\
2 \times 10^{-16} \\
\mathrm{NA} \\
6,84 \times 10^{-5} \\
5,92 \times 10^{-7} \\
1,38 \times 10^{-7} \\
\mathrm{NA}\end{array}$ \\
\hline
\end{tabular}

Sumber: Data diolah, 2021

\subsection{Pemilihan Model GARCH Asimetris}

Pemilihan model dilakukan dengan memilih model yang signifikan dan memiliki nilai AIC terkecil. Berdasarkan hasil estimasi parameter model TGARCH dan EGARCH pada subbab sebelumya diketahui hanya model EGARCH(1,1),EGARCH(1,2), TGARCH(1,1), dan TGARCH $(1,2)$ yang signifikan. Oleh karena itu, perhitungan nilai AIC hanya akan dilakukan terhadap model tersebut. Adapun nilai AIC model TGARCH dan EGARCH return $\mathrm{BCA}$ serta Bank Mandiri disajikan pada Tabel 16 dan 17.
Tabel 16. Nilai AIC Model EGARCH dan TGARCH Return BCA

\begin{tabular}{|c|c|}
\hline Model & AIC \\
\hline EGARCH(1,1) & $-5,2985$ \\
\hline EGARCH(1,2) & $\mathbf{- 5 , 3 0 2 1}$ \\
\hline TGARCH(1,1) & $-5,2471$ \\
\hline TGARCH(1,2) & $-5,2388$ \\
\hline
\end{tabular}

Sumber: Data diolah, 2021

Tabel 17. Nilai AIC Model EGARCH dan TGARCH Return Bank Mandiri

\begin{tabular}{|c|c|}
\hline Model & AIC \\
\hline EGARCH(1,1) & $-5,2985$ \\
\hline EGARCH(1,2) & $\mathbf{- 4 , 8 0 1 6}$ \\
\hline TGARCH(1,1) & $-4,7838$ \\
\hline TGARCH(1,2) & $-4,7836$ \\
\hline
\end{tabular}

Sumber: Data diolah, 2021

Tabel 16 dan 17 menunjukkan bahwa nilai AIC terkecil di antara model EGARCH dan TGARCH return saham BCA dan Bank Mandiri terdapat pada model EGARCH $(1,2)$. Oleh karena itu, model yang dipilih di sini adalah model $\operatorname{EGARCH}(1,2)$. Berdasarkan model EGARCH pada persamaan (8) dan nilai parameter $\alpha_{0}, \alpha_{1}, \gamma_{1}, \beta_{1}$ dan $\beta_{2}$ model EGARCH(1,2) pada Tabel 14 dan 15, maka model $\operatorname{EGARCH}(1,2)$ data return saham BCA dan Bank Mandiri secara berturut-turut adalah:

$$
\begin{aligned}
\ln \left(\sigma_{t B}^{2}\right)= & -0,271973-0,056156 \\
& \frac{\left|a_{t-1}\right|+0,236644 a_{t-1}}{\sigma_{t-1}}+ \\
& 0,544845 \ln \left(\sigma_{t-1}^{2}\right) \\
& +0,419495 \ln \left(\sigma_{t-2}^{2}\right) \\
\ln \left(\sigma_{t C}^{2}\right)= & -0,307281-0,062306 \\
& \frac{\left|a_{t-1}\right|+0,237967 a_{t-1}}{\sigma_{t-1}}+ \\
& 0,507072 \ln \left(\sigma_{t-1}^{2}\right) \\
+ & 0,450842 \ln \left(\sigma_{t-2}^{2}\right) .
\end{aligned}
$$

\subsection{Peramalan Volatilitas}

Peramalan volatilitas dilakukan untuk 14 periode berikutnya yaitu dari 24 Mei 2021 sampai 10 Juni 2021. Volatilitas saham BRI diramalkan dengan menggunakan model $\operatorname{GARCH}(1,2)$, sedangkan volatilitas saham BCA dan Bank Mandiri diramalkan dengan menggunakan model $\operatorname{EGARCH}(1,2)$. Peramalan volatilitas dilakukan dengan 
menggunakan software $R$. Adapun hasil peramalan volatilitas saham BRI, BCA, dan Bank Mandiri pada 14 periode berikutnya dapat dilihat pada Tabel 18 serta secara grafis dapat dilihat pada Gambar 7.

Tabel 18. Hasil Peramalan Volatilitas

\begin{tabular}{|c|c|c|c|}
\hline Waktu & $\begin{array}{c}\text { Nilai } \\
\text { Volatilitas } \\
\text { BRI }\end{array}$ & $\begin{array}{c}\text { Nilai } \\
\text { Volatilitas } \\
\text { BCA }\end{array}$ & $\begin{array}{c}\text { Nilai } \\
\text { Volatilitas } \\
\text { Bank } \\
\text { Mandiri }\end{array}$ \\
\hline 24 Mei 2021 & 0,01592795 & 0,01313 & 0,02175 \\
\hline 25 Mei 2021 & 0,01638232 & 0,01354 & 0,02064 \\
\hline 26 Mei 2021 & 0,01647781 & 0,01360 & 0,02134 \\
\hline 27 Mei 2021 & 0,01671901 & 0,01381 & 0,02120 \\
\hline 28 Mei 2021 & 0,01688914 & 0,01395 & 0,02144 \\
\hline 31 Mei 2021 & 0,01708209 & 0,01412 & 0,02150 \\
\hline 1 Juni 2021 & 0,01725771 & 0,01427 & 0,02165 \\
\hline 2 Juni 2021 & 0,01743364 & 0,01443 & 0,02175 \\
\hline 3 Juni 2021 & 0,01760256 & 0,01459 & 0,02187 \\
\hline 4 Juni 2021 & 0,01776791 & 0,01474 & 0,02197 \\
\hline 7 Juni 2021 & 0,01792845 & 0,01489 & 0,02208 \\
\hline 8 Juni 2021 & 0,01808497 & 0,01503 & 0,02218 \\
\hline 9 Juni 2021 & 0,01823735 & 0,01518 & 0,02228 \\
\hline 10 Juni 2021 & 0,01838587 & 0,01532 & 0,02238 \\
\hline Sumer Dat
\end{tabular}

Sumber: Data diolah, 2021

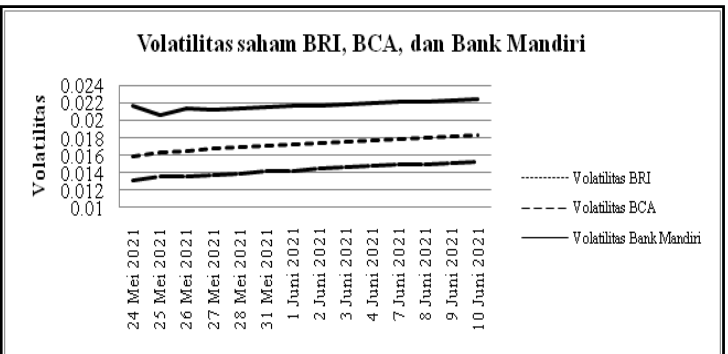

Gambar 7. Peramalan Volatilitas saham BRI, BCA, dan Bank Mandiri

Berdasarkan hasil peramalan volatilitas saham BRI, BCA, dan Bank Mandiri pada Tabel 18 serta grafik hasil peramalan volatilitas pada Gambar 7 diketahui bahwa volatilitas saham BRI, BCA, dan Bank Mandiri cenderung mengalami peningkatan dari periode ke periode. Hasil peramalan volatilitas saham BRI berkisar dari 0,01592795 sampai 0,01838587, BCA berkisar dari 0,01313 sampai 0,01532, dan Bank Mandiri berkisar dari 0,02064 sampai 0,02238 . Kisaran nilai tersebut menunjukkan bahwa volatilitas tertinggi terdapat pada saham Bank Mandiri dan volatilitas terendah terdapat pada saham BCA.

\subsection{Estimasi VaR}

Perhitungan VaR dilakukan dengan menggunakan persamaan (10), pada holding period satu hari, dan selang kepercayaan $95 \%$. Pada penelitian ini diasumsikan bahwa dana investasi yang digunakan sebesar Rp10.000.000,00. Estimasi VaR dilakukan dengan menggunakan software excel. Berdasarkan hasil peramalan volatilitas pada Tabel 18, diperoleh estimasi VaR yang disajikan pada Tabel 19 dan disajikan dalam bentuk grafis pada Gambar 8 .

Tabel 19. Estimasi Value at Risk (VaR) saham BRI, BCA, dan Bank Mandiri

\begin{tabular}{|c|c|c|c|}
\hline Waktu & $\begin{array}{c}\text { Var Saham } \\
\text { B RI }\end{array}$ & $\begin{array}{c}\text { VaR Saham } \\
\text { BCA }\end{array}$ & $\begin{array}{l}\text { VaR Saham } \\
\text { B ank Mandiri }\end{array}$ \\
\hline 24 Mei 2021 & $\operatorname{Rp} 262.811,18$ & Rp216.645,00 & Rp358.875,00 \\
\hline 25 Mei 2021 & Rp270.308,28 & Rp223.410,00 & Rp340.560,00 \\
\hline 26 Mei 2021 & $\operatorname{Rp} 271.883,87$ & $\operatorname{Rp} 224.400,00$ & $\operatorname{Rp} 352.110,00$ \\
\hline 27 Mei 2021 & Rp275.863,67 & Rp227.865,00 & Rp349.800,00 \\
\hline 28 Mei 2021 & Rp278.670,81 & Rp230.175,00 & Rp353.760,00 \\
\hline 31 Mei 2021 & Rp281.854,49 & Rp232.980,00 & Rp354.750,00 \\
\hline 1 Juni 2021 & Rp284.752.22 & Rp235.455,00 & Rp357.225,00 \\
\hline 2 Juni 2021 & Rp287.655,06 & Rp238.095,00 & Rp358.875,00 \\
\hline 3 Juni 2021 & Rp290.442,24 & Rp240.735,00 & $.855,00$ \\
\hline 4 Juni 2021 & Rp293. & Rp243.210,00 & $.505,00$ \\
\hline 7 Juni 2021 & Rp295.819,43 & Rp245.685,00 & Rp364.320,00 \\
\hline 8 Juni 2021 & Rp298.402,01 & Rp247.995,00 & Rp365.970,00 \\
\hline 9 Juni 2021 & Rp300.916,28 & Rp250.470,00 & Rp367.620,00 \\
\hline 10 Juni 2021 & Rp303.366,86 & Rp252.780,00 & Rp369.270,00 \\
\hline Rata-rata & Rp285.422,63 & Rp236.421,43 & Rp358.278,46 \\
\hline
\end{tabular}

Sumber: Data diolah, 2021

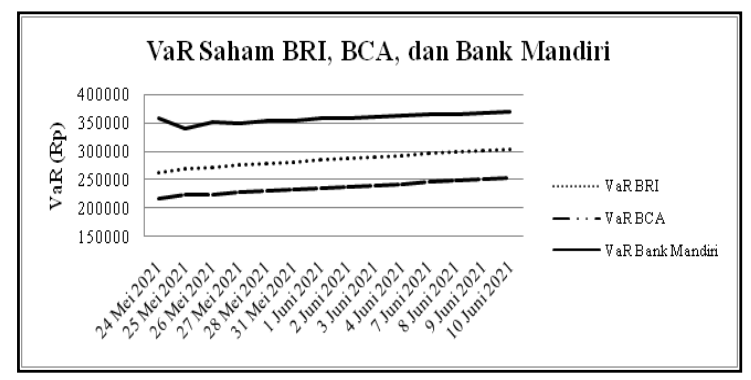

Gambar 8. Estimasi VaR saham BRI, BCA, dan Bank Mandiri

Berdasarkan Tabel 19 estimasi nilai VaR saham BRI pada tanggal 24 Mei 2021 yaitu Rp262.811,18. Hal ini berarti apabila investor berinvestasi pada saham BRI sebesar Rp10.000.000,00, pada holding period satu hari, dan selang kepercayaan 95\%, maka terdapat keyakinan sebesar $95 \%$ kerugian maksimum yang ditanggung investor sebesar Rp262.811,18 atau dengan kata lain terdapat kemungkinan sebesar 5\% kerugian yang ditanggung oleh investor lebih dari Rp262.811,18. VaR saham BRI berkisar dari Rp262.811,18 sampai Rp303.366,86 dengan nilai VaR terendah terdapat pada tanggal 24 Mei 2021 dan VaR tertinggi terdapat pada tanggal 10 Juni 2021. Saham BRI memiliki nilai rata-rata VaR sebesar Rp285.422,63. 
Hal yang sama juga bisa dijelaskan untuk nilai VaR BCA dan Bank Mandiri untuk setiap periodenya cenderung mengalami peningkatan dari periode ke periode yang juga dapat diamati melalui Gambar 8. Berdasarkan nilai rata-rata VaR dari masing-masing saham diketahui bahwa saham Bank Mandiri memiliki tingkat risiko investasi tertinggi dan BCA memiliki tingkat risiko investasi terendah. Sehingga dapat disarankan bagi investor yang menyukai risiko dapat memilih berinvestasi pada saham Bank Mandiri dan bagi investor yang tidak menyukai risiko dapat berinvestasi pada saham BCA.

\section{SIMPULAN DAN SARAN}

Setelah dilakukan analisis terhadap data harian harga penutupan saham BRI, BCA, dan Bank Mandiri, diperoleh simpulan yaitu:

Di antara model GARCH, TGARCH, dan EGARCH, model terbaik untuk memodelkan volatilitas saham BRI adalah model $\operatorname{GARCH}(1,2)$. Sedangkan model yang digunakan untuk memodelkan volatilitas saham BCA dan Bank Mandiri adalah model $\operatorname{EGARCH}(1,2)$.

Hasil peramalan volatilitas saham BRI, BCA, dan Bank Mandiri pada empat belas periode berikutnya yaitu 24 Mei 2021 sampai 10 Juni 2021 cenderung menunjukkan peningkatan dari periode ke periode. Volatilitas tertinggi terdapat pada saham Bank Mandiri dan volatilitas terendah terdapat pada saham BCA.

Berdasarkan hasil estimasi nilai VaR dengan menggunakan tingkat kepercayaan $95 \%$, holding period satu hari, dan investasi awal Rp10.000.000,00, estimasi nilai VaR dari saham BRI, BCA, dan Bank Mandiri cenderung mengalami peningkatan dari periode ke periode. Rata-rata VaR dari saham BRI, BCA, dan Bank Mandiri secara berturut-turut adalah Rp285.422,63, Rp260.944,59, dan Rp383.745,15. Hal ini berarti saham Bank Mandiri memiliki tingkat risiko investasi tertinggi dan BCA memiliki tingkat risiko investasi yang terendah.

Mengingat dalam penelitian ini diketahui saham BCA dan Bank Mandiri bersifat asimetris sehingga dimodelkan dengan menggunakan model GARCH asimetris. Berdasarkan nilai AIC dan hasil estimasi parameter, diketahui model EGARCH merupakan model yang lebih baik dibandingkan model TGARCH untuk meramalkan volatilitas saham BCA dan Bank Mandiri. Oleh karena itu, dapat disarankan bagi penelitian selanjutnya yang ingin meramalkan volatilitas data harga saham yang bersifat asimetris dapat menggunakan model EGARCH. Selain itu, disarankan juga bagi penelitian selanjutnya untuk membandingkan model EGARCH dengan model asimetris lainnya.

\section{DAFTAR PUSTAKA}

Bursa Efek Indonesia. 2020. Saham. https://www.idx.co.id/produk/saham/. Diakses 16 Agustus 2020 (21:21 WITA).

Damiyanti, D. P. D., Dharmawan, K., and Harini, L. P. I. 2018. Perhitungan Value at Risk dengan Penduga Volatilitas Stokastik Heston. E-Jurnal Matematika, 7(4), pp. 317-321.

Danielsson, J. 2011. Financial Risk Forecasting. United Kingdom: John Wiley and Sons.

Dwipa, N. M. S. 2016. Peramalan Value at Risk Menggunakan Metode GARCH. Buletin Ilmiah Mat. Stat, dan Terapannya, 5(2), pp. 267-276.

Jorion, P. 2007. Value at Risk the New Benchmarkfor Managing Financial Risk.United States of America:McGrawHill Companies.

Maruddani, D. A. I., and Purbowati, A. 2009. Pengukuran Value at Risk pada Aset Tunggal dan Portofolio dengan Simulasi Monte Carlo. Jurnal Media Statistika, 2(2), pp. 93-104.

Peraturan Otoritas Jasa Keuangan Nomor 56/POJK.03/2016, Pub. L. No. 3 (2016).

Puspitasari, I. 2020. Banyak Diburu Asing, Ini Rekomendasi Analis untuk Saham Perbankan.

https://investasi.kontan.co.id/news/banyakdiburu-asing-ini-rekomendasi-analis-untuksaham-perbankan. Diakses 5 Oktober 2020, (10;15 WITA).

Tsay, R. S. 2013. An Introduction to Analysis of Financial Data with $R$. Canada: John Wiley and Sons. 
Tyas, M. D. P., Maruddani, D. A. I., and Rahmawati, R. 2019. Perhitungan Value at Risk dengan Pendekatan Threshold Autoregressive Conditional Heteroscedasticity-Generalized Extreme Value. Jurnal Media Statistika, 12(1), pp. 73-85. 